\title{
The Agency of Iroquois Women through Corn Production
}

\author{
David Perrotto $^{\mathrm{a}}$
}

\begin{abstract}
Native American tribes often used food as a means of currency. Surpluses of food were often bartered with other tribes for food items or supplies. The most popular food that was bartered and traded was corn. Among the Iroquois, it was the woman's responsibility to grow, harvest, and prepare the corn for both food and ceremonial services for the tribe and trade with others. This paper focuses on the importance of Iroquois women, with particular emphasis on the Mohawk and Seneca tribes. It will explain their role in farming the corn and how they gained agency within their tribes because of their responsibility for tending to the corn crops, an important commodity to the tribe. It will also briefly touch upon the ways that their creation myth was tied to Iroquois views of women and corn. This paper will analyze the firsthand accounts of Father Joseph Lafitau, Henry Hudson, and General John Sullivan. It will also utilize the works of scholars such as of Daniel K. Onion, John P. Hart, Judith K. Brown, Sara Henry Stites, and Arthur C. Parker to link the responsibility of women in corn production to the privileges they received in the tribe and their agency in Iroquois society.
\end{abstract}

Keywords: Iroquois, Women, Corn, Mohawk, Seneca

\section{Women, Corn, and Creation}

James Axtell writes that just as Christians had their creation story the Indians had their own as well. Although both myths were similar, the most noticeable differences were in how the women were portrayed and how the created humans viewed nature. The Iroquois viewed their women as life givers bringing about all of humanity and forming a symbiotic relationship with the animals in order to form the earth. The Christian Europeans on the other hand viewed their women as the cause of sin and temptation. The earth had already existed by the time the humans were created and God had given the humans full domain over the animals to do with them what they pleased. The creation story of the Christians portrays humans as the dominant beings on the earth and their women as a curse; however, the Iroquois creation myth portrays the humans as dependent upon nature and they viewed their women as a blessing.

Iroquois women were naturally given agency, manipulative powers within the tribe, due to their role in the Iroquois creation story and their role as a mother and birth giver in their tribe. The Iroquois creation story, as stated by John Witthoft, an anthropologic student of the Iroquois in Delaware, in the book, The Great Tree and the Longhouse: The Culture of the Iroquois, edited by Hazel W. Hertzberg, writes: In the beginning there was no world other than the sky world where there was a man and a wife who was expecting a child (as cited in Axtell, 1981, p. 174). The wife fell through a hole in the sky world and built the earth on the back of a turtle with soil from the bottom of the ocean. She would walk around the earth and when she gave birth to her daughter, she also walked around the world with her mother in order to keep the earth growing (as cited in Axtell, 1981, p. 176). The daughter eventually met a man and became pregnant, but died while giving birth to two twin boys. When she was buried the twins and grandmother planted three plants on her grave that are still used by the tribe. These plants are, corn, beans, and squash (as cited in Axtell, 1981, p. 177). The twins created the animals and the food that the animals were to eat. The twins then completed their creations and had a duel in which one of the twins was killed. The surviving twin killed his grandmother by beheading her and throwing her head up into the sky, which became the moon (as cited in Axtell, 1981, p. 178).

This creation story is mainly focused around the women who first created and brought life to the earth, and then in their deaths give the earth and surviving population gifts that they can use throughout their lives. The myth also shows how women played a proactive role in the formation of the earth, while the men played a passive role.

\section{Introduction of Corn in Iroquois Society}

When corn was introduced into the Eastern Woodlands its growth relied heavily on human interactions and the crops were highly sensitive to weather and soil conditions. This played a role in forming permanent civilizations. John P. Hart, Robert G. Thompson, and Hetty Jo Brumbach (2003) writes that corn is often used as an enabler, if not the catalyst, for the development of settled village life (p. 619). Hart (2001) also states that the archeological evidence suggests that corn was introduced to the new world as early as the first century B.C.; however, the Iroquois only adapted maize base agriculture around 1300 A.D. (p. 159). This is known due to recent accelerator mass spectrometry dating, and this resulted to the transformation of a hunter - gather tribe to a localized stable community. Hart (2003) states that [t]he structure of maize populations was important in the evolution of maize agriculture in the Eastern Woodlands of North America (p. 155). He also states that "[t]he structure of the maize populations relied on the structure of the human community that consisted of postmarital residence patterns which affected the distributions of males and females relative to their natal families and maternal and paternal relatives within and between populations" (Hart, 2001, p. 161). The Iroquois would preserve their knowledge of agriculture by passing information about corn and corn growing to each successive generation. This is important because women were the dominating force responsible for tending to the crops. The most important aspect of matrilocal residence for the 
evolution of maize agriculture was the establishment of intra and intergenerational continuity in agricultural management (Hart, 2001, p. 155). The Iroquois would preserve their knowledge of agriculture by passing information about corn and corn growing to each successive generation. Archeological evidence suggests that tools and artifacts that were used in corn production were perpetuated through each successive generation by the daughters of the previous generation. Women in patrilocal populations had the potential to share information about maize cultivation between intermediate and extended families. Hart (2001) asserts that "the evolution of maize agriculture in the Eastern Woodlands of North America was opportunistic: it was affected by chance and drift, and by selection working on variation in maize and human populations and on variation in interactions of those populations" (p. 155). The archeological evidence suggests that the corn populations in North America caused the settlement of the indigenous population, but the historical evidence shows that corn was used as a food source as well as a type of currency.

\section{Importance of Corn}

As previously stated, the Iroquois depended upon crops such as corn as a major source of their food supply as well as for currency. Stites (1904) states that, "[m]aize preparations of various sorts were the staple food of the village and made up the bulk of the stored surplus" (p. 65). Corn was the main crop of the Iroquois and it was one of the three major foods mentioned in the Iroquois creation story. It was so important to the Iroquois that "they called it by a name meaning 'our life' or 'it sustains us'" (Parker, 1968, p. 9). Explorers who traveled to Northeast part of America saw fields of corn that were cared for by Iroquois tribes. On September $13^{\text {th }}, 1609$, Henry Hudson wrote in his journal while he was traveling across the Hudson River. "I saw there a house wellconstructed of oak bark... a great quantity of maize or Indian corn and beans of last year's growth, and there lay near the house for the purpose of drying enough to load three ships, besides what was growing in the fields" (De Laet, 1841, p. 16). This letter from General John Sullivan (1779) to George Washington, concerning his attack on the Seneca tribe in 1779, will show the extent on which the Iroquois depended upon the corn:

The troops remained on the ground three whole days destroying the Towns \& Corn Field. I never saw finer corn altho' it was planted much thicker than is common with our Farmers. The quantity of Corn and other vegetables destroyed at the several Towns, from the best accounts I can collect from the officers employed to destroy it must certainly exceed five hundred acres which is a low estimate and the plunder is estimated at 30m Dollars.... (p. 19).

Historian Daniel K. Onion states that "unlike the grains of Europe, corn did not require large areas of carefully cultivated ground" (Onion, 1964, p. 60). General Sullivan's scorched earth policy destroyed peaceful villages and fertile fields barely leaving any food for the upcoming winter. Since the corn wasn't grown in large open areas, five hundred acres yielded a substantial amount of corn that was used for both food and currency. The destruction of five hundred acres put a toll on the Iroquois' economy and diet.
Corn was used as an important currency for trading with other tribes. According to Onion, the Mohawks developed a society similar to other Iroquois tribes dependent on corn. The Mohawks "split from the main body of Iroquois in the Great Lakes region after the Iroquois moved up from the south or southwest" (Onion, 1964, p. 60). The Mohawks moved further north into present day Quebec and formed a village called Hochelaga, and acquired corn by raiding southern tribes like the Seneca (Onion, 1964, p. 60). Most of the corn that was found in the Mohawk villages was found in southern parts of America. The Mohawks used corn to trade with the Adirondacks for meat; however, if "the Adirondack tribes failed to produce any type of meat the Mohawks tried hunting themselves" (Onion, 1964, p. 60). Their success at hunting angered the Adirondack tribes because it deprived them of corn. The result was a war erupted between the Mohawks and Adirondacks and the Mohawks "eventually conquered down into New York State where they became warriors and hunters as well as growers of corn" (Onion, 1964, p. 60). The Mohawks settled in present day New York and began to set up a civilized tribe, with a distinct division of labor.

The Iroquois, like many other civilized nations, had a distinct division of labor between the sexes. Parker (1968) states that: "the Iroquois were too busy with their conquests to engage in field work" (p. 22). Gender roles provided an advantage to the tribes by utilizing the women to take control of the inner workings of the tribe while the men were away. It was the role of the men to hunt and bring back game and to "stand ready to defend their people and property and to engage in war expeditions" (Parker, 1968, p. 22). While the women, according to Brown, "were in charge of the ingenious methods of preserving and storing the abundant food supplies". The role of the men empowered the women to take command of the fields and make it their responsibility to grow corn and other types of food to provide to the tribe.

\section{Corn Products}

The Mohawk and Seneca women grew a wide variety of corn for a myriad of purposes. The Mohawks mostly grew a type of corn called indurate, flint or hominy corns, which comprised the highest percentage of the corn crop (Onion, 1964, p. 60). Other types of corn that the Mohawk women grew were: amylace (starch or bread corns), everta (popcorn), saccharata (sweet corn), amylea-saccharata (starchy sweet corn) (Onion, 1964, p. 60). The different types of corn that the women grew were used to make different types of corn products.

The Seneca women also grew different types of corn as well, and they also used the different types of corn to make a variety of corn products. Stites (1904) states, "Among the Senecas three kinds of corn were raised; the white flint for hominy, the red for storing - charred or dried- and white for grinding into flour and baking bread" (p. 57). The Seneca women grew different types of corn for the purpose of consumption and storage to be eaten at a later time during the winter season or to be used for trading. There were two important corn products that the women prepared. First was the $o$ no kwa, a hulled corn dish. It was used during medical society meetings, church and Sunday gatherings, or a war dance (Harrington, 1908, 582). This corn dish was important for consumption and ceremonial uses. Another type of corn 
that was important to the Seneca was gagai'te oa ' $k w a$, it was used by the women to make corn bread. The women would hull it, turn it into a flour, and mix it with ashes and hot water to make a thick dough (Harrington, 1908, p. 585). Robert Juet, a sailor on the Half Moon, wrote in his journal on September $4^{\text {th }}, 1609$, “.... They have a great store of corn whereof they make good bread" (p. 16). The Iroquois had a large variety of corn and were used for specific reasons, but to grow them took a lengthy process that the women were responsible for.

\section{Women's Role in Planting and Growing the Corn}

The Mohawks would clear the land that they would want to start planting on "by girdling, or the removal of a complete strip of bark from the tree in order to kill it, all the trees in an area". Col. James Smith, a captive and, eventually, adopted into the Caughnewaga Mohawk tribe in the 1750's, writes that, "The planting season for the Mohawk was anticipated as early as the end of March, and that the sugaring group finished up their collection of maple sugar in late March and 'began to prepare for moving into town, in order to plant corn.' Final preparations of the fields were made in late April or early May" (Onion, 1964, p. 61). The women would prepare the corn seeds for germination. "[They] would start the seeds in seed - beds on bark in the longhouses. If there was no time to do this, the seeds were soaked in a solution which contained extracts of hellebore and other roots; this treatment was supposed to make the seed corn distasteful to marauding crows" (Onion, 1964, p. 63). In the Mohawk tribe, the women had a very important role in preserving the corn as well as planting it. Men played a small role in the cultivation of corn and worked alongside the women in the field temporarily, but the women took responsibility in processing the corn.

\section{Women's role in harvesting Corn}

Women were responsible for processing the corn to feed the community. Green corn appeared in mid - August and could be eaten in a variety of ways. According to Onion, "Green corn was used in several ways. To be eaten on the cob, unhusked ears were either boiled in clay vessels or bark containers over open fires, or baked in the ashes of a fire, covered with a layer of dead coals, then with a layer of hot coals" (Harrington, 1908, p. 580). Women used many tools to prepare the corn. One tool that was used by both the Mohawk and the Seneca was the yega 'so' gaya' tha, or the scraper. It was made out of the mandible, bottom jaw, of a deer (Harrington, 1908, p. 580). This tool was used to scrape corn from the cob, and the corn could be made into a variety of products. Since women had the responsibility of harvesting and cooking the food, they were also in charge of its preservation. According to Judith K. Brown:

Iroquois women were in charge of the ingenious methods of preserving and storing abundant food supplies. Corn, meat, fish, berries, squashes, and even fats were preserved. Some of these foods were buried in specially constructed pits, and some were kept in the long house. Stored food constituted one of the major forms of wealth of the tribe (Brown, 1970, p. 163).

Women were ultimately given the responsibility to grow and preserve the food and money supply of the tribe, and because of this responsibility, they were allowed more agency within their community compared to European women.

\section{Agency through Corn}

Iroquois society throughout the six nations is patriarchal and the male chiefs had the final say in all tribal matters; however, women were granted a considerable amount of agency within their tribe because of their role in corn production and preservation. The women had domain over everything inside the tribe, because they were taking care of it, as well as anything that a woman brought into the tribe was then considered that woman's property. For example: It was customary for the men to be very generous with the game they brought back because when it was brought back by a male it was considered public property; however, this was different if food was brought back by a woman. In order for the men to get around this tradition, they would hide the food in the woods and have their wives bring it back to the tribe. According to Parker; "She was not bound to give her husband's bounty and could properly refuse the appeals of the hungry, lazy, or others who loved to prey on generosity" (Parker, 1968, p. 22-23). And while the men hunted, the women were responsible for caring for all matters inside the tribe which included motherly duties, crop cultivation and food production. John N.B. Hewitt states, "Women owned the lands, the village sites and the burial grounds"(as cited in Brown, 1970, p. 160). George Synderman acknowledges the proof of female ownership by citing a statement by Red Jacket, speaker for the women at the Council of 1791; "You ought to hear and listen to what we women shall speak... for we are the owners of the land and it is ours... (as cited in Brown, 1970, p. 160)." Father Joseph Lafitau also confirms this when he was living with the Iroquois tribes. He states: "Nothing, however is more real than the superiority of the women.... The land, the fields and their harvest all belong to them" (as cited in Brown, 1970, p. 153). This privilege of land ownership comes from the responsibility of the women tending to it while the men were away hunting, trading, and fighting. This land ownership was very important to women's agency in the tribe because, like in any other civilized community, land ownership meant eligibility for government participation.

Iroquois women derived their agency in government through their ownership of the land. According to historian Barabra A. Mann (2000):

The gantowisas enjoyed sweeping political powers, which range from the administrative and legislative to the judicial. The gantowisas ran the local clan councils... They nominated all the male sachems as well as all Clan Mothers to office and the power to impeach wrong doers. They appointed warriors, declared war, negotiated peace, and mediated disputes (p. 116-117).

Iroquoian women enjoyed these privileges due to their ownership of the land. The women were allowed to elect and impeach male leaders. Reverend Ashur Wright, missionary among the Iroquois, states:

The women were the great power among the clans, as everywhere else. They did not hesitate, when occasion required, to 'knock the horns', as it was technically called, from the head of a chief and send him back to the ranks of the 
warriors. The original nomination of the chiefs also always rested with them (as cited in Brown, 1970, p. 154).

This was a unique situation in which the women were allowed opportunity to give status to the men. The women also elected a Clan Mother. The Clan Mother was usually an elder with a lot of experience. The Clan Mothers oversaw the entire tribe and each Iroquois nation was required to have one Clan Mother that would oversee the leadership and economic prosperity of the tribe. The Clan Mothers were also given privileges to forge alliances with outside nations and other Iroquois tribes. Molly Brant is an example of a Clan Mother who was able to use her influence to have her tribe join the side of the British during the American Revolution, and to coerce her tribe into attacking fellow Iroquois.

\section{Forging Alliances}

Molly Brant was a prominent Mohawk woman who used her agency to forge an alliance with the British during the American Revolution. At the time, the Iroquois were loyal to the French. Jesuit missionaries were establishing themselves in American since the 1600's, and started doing missionary works initially with the Hurons and eventually the Iroquois. The missionaries converted, traded, and cared for the Iroquois up until 1763 when their order was liquidated in France. The British were able to move in on the Iroquois when the French were expelled from the Louisiana area. One person in particular was William Johnson, an Irish national who was appointed to be superintendent of Indian affairs (Graymont, 1972, p. 30). He was involved with the fur trade and became acquainted with the local Mohawk tribe in New York. He felt that securing relations with the women would give him an advantage with the Iroquois and secure his fortune with the fur trade (Gross, 1999, p. 27).

William fancied Molly who was the daughter of the chief and took her as his consort and this benefitted him in his business, through access to Iroquois lands but most importantly, during the American Revolution. With the help of Molly, Johnson lobbied the Mohawks for their support in helping the British. The British desperately needed him to obtain their support because of their lack of manpower. Molly had the power to influence the Mohawk tribe in helping the British fight in the Revolution. Gross noted that: She was effective, for a time, in convincing the Mohawks and the Seneca that their tribal interests resided with the British, even convincing the Seneca to take the field against colonials at Oriskany (Gross, 1999, p. 32). Her influence among the tribes was very strong. . Molly was able to negotiate with tribal leaders when the Europeans failed. Gross compares her to both Pocahontas and Sacajewea. Gross (1999) states "Like Sacajewea, Molly interpreted her culture for white men who need her expertise. Like Pocahontas, Molly's most significant relationship was a liaison with a white man of power" (p. 37). Johnson trusted her to move freely among the tribes and associate herself with other white people. However; Brant's determination to help Johnson and the British eventually damaged the wellbeing of the Iroquois.

The two participants of the American Revolution used Native American allies to help over power the other side. The Mohawks and the Seneca fought alongside the British, due to the orders of Molly Brant. The Colonists aligned themselves with the Oneida tribe. According to David Levinson, author of An Exploration for the Oneida-Colonist Alliance in the American Revolution, The Oneidas served the Colonists as messengers, diplomatic representatives, guides, interpreters, informers, spies, and warriors. They participated in two major battles (Oriskany and Saratoga), two minor battles (Barren Hill and Klock's Field), one siege (Ft. Stanwix), one campaign (Sullivan's of 1779), and a number of raids and skirmishes (Levinson, 1976, p. 270). The Oneida's involvement in the Revolution on the side of the Colonists was important because it prevented the British from controlling territory west of the Hudson River. Also, it showed the division of tribal interests and how one woman was able to use her influence to coerce her tribe to fight with another fellow tribe. Brant was able to use her influence to help her husband gain economic and diplomatic alliances with her tribe. This allowed him to become successful in the fur trade, and give him more clout with Britain for recruiting native tribes to aid the cause of the Crown.

Overall the women's control of food and economic supply, through the corn, led them to have more agency and power within their tribes than their European counterparts. This patriarchal society was more willing to give women privileges because of their role in the creation of the earth and their responsibility in corn production. The women had ultimate dominion inside the tribal walls. They were responsible for tending to and harvesting the corn, as well as, watching over the young while the men were away. This has led them to have the land and the fields registered in their names. They also had control of what grew from the fields and who they decided to share their bounty with. The women's control of the land and food supply made them politically powerful as well. They were able to subdue war plans the men had made by denying them food, or the women would actually have the power to declare war on another tribe. They were also the ones who were able to choose the tribal chief and reprimand those who stepped out of line. The women also had the power to forge alliances with other tribes and with foreign nations such as the colonists and the British. The corn crop was the life force of the Mohawk and Seneca tribes, and the role of women in growing and preparing the corn was undeniably important.

\section{References}

Axtell, J. (1981). The Indian Peoples of Eastern America: A Documentary of the Sexes. New York,New York: Oxford University Press

Brown, J. K. (1970). Economic Organization and the Position of Women among the Iroquois. Ethnohistory, Vol. 17, No. 3/4, pp (151-167). Duke University Press

Graymont, B. (1972). The Iroquois in the American Revolution. Syracuse, New York: Syracuse University Press.

Gross, J. (1999). Molly Brant: Textual Representations of Cultural Midwifery, American Studies, Vol. 40 No.1, pp (23-40). Mid-America American Studies Association

Hart, J. P. (2001). Maize, Marilocality, Migration, and Northern Iroquoian Evolution. Journal of Archaeological Method and Theory, Vol. 8, No. 2, pp (151- 182). Springer

Hart, J. P., Thompson, R. G., Brumbach, H. J. (2003). 
Phytolith Evidence for Early Maize (Zea Mays) in the Northern Finger Lakes Region of New York. American Antiquity, Vol. 68, No. 4, pp (619-640). Society for American Archaeology

Levinson, D. (1976). An Exploration for the Oneida- Colonist Alliance in the American Revolution, Ethnohistory, Vol. 23, No. 3, pp (265-289). Duke University Press

Mann, B. A. (2004). Iroquoian Women: The Gantowisas, New York: Peter Lang Publishing, Inc
Onion, D. K. (1964). Corn in the Culture of the Mohawk Iroquois, Economic Botany, Vol. 18, No. 1, pp (60-66). Springer

Parker, A. C. (1910). Iroquois Uses of Maize and Other Food Plants, Albany, New York: University of the state of New York

Stites, S. (1904). Economics of the Iroquois, Lancaster, P.A.: The New Era Printing Company 